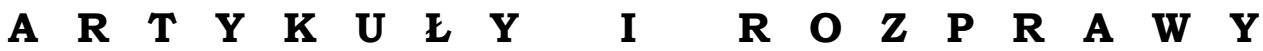

Józef Porayski-Pomsta

DOI: 10.33896/PorJ.2021.6.1

(Towarzystwo Kultury Języka, Warszawa,

e-mail: j.porayski-pomsta@uw.edu.pl)

ORCID: 0000-0002-0524-8668

\section{LOGOPEDIA W UNIWERSYTECIE WARSZAWSKIM}

\section{WPROWADZENIE}

W 2018 roku w tomie X „Studiów Pragmalingwistycznych” opublikowałem wspólnie $z$ dr Danuta Emilutą-Rozya obszerne, niemal 30-stronicowe studium Logopedia warszawska. Historia i czasy współczesne. ${ }^{1}$ Do tego opracowania będę się odwoływał.

W tym artykule skupię się na historii logopedii w Uniwersytecie Warszawskim, marginalnie traktując rozwój logopedii w Wyższej Szkole Pedagogiki Specjalnej i Akademii Pedagogiki Specjalnej im. Marii Grzegorzewskiej w Warszawie oraz rolę, jaką odegrała Sekcja Logopedyczna Towarzystwa Kultury Języka w rozwoju logopedii w Warszawie i w Polsce.

Omówię, ograniczajac się zasadniczo do językoznawstwa polonistycznego i eksperymentalnych badań fonetycznych, które rozwijały się w Uniwersytecie Warszawskim w okresie międzywojennym i były kontynuowane do połowy lat sześćdziesiątych XX wieku, wpływ tych badań na kształtowanie się logopedii. Tego omówienia dokonam poprzez przypomnienie kilku badaczy, którzy - moim zdaniem - najmocniej wpłynęli na początki i rozwój logopedii w Uniwersytecie Warszawskim.

W drugiej części opracowania przedstawię historię kształcenia logopedów w Uniwersytecie Warszawskim.

\section{JĘZYKOZNAWSTWO I LOGOPEDIA}

Tradycję warszawskiego językoznawstwa polonistycznego - jak wiadomo - tworzyli tacy uczeni jak Jan Baudouin de Courtenay, Tytus Benni, Stanisław Szober, Witold Doroszewski, Halina Koneczna, Stanisław Skorupka, Jan Tokarski, Halina Kurkowska, Danuta Buttler, Mieczysław Szymczak. Językoznawstwo to od początku swego istnienia kierowało się ku społecznym, komunikacyjnym i fizjologicznym aspek-

1 J. Porayski-Pomsta, D. Emiluta-Rozya, Logopedia warszawska. Historia i czasy współczesne, „Studia Pragmalingwistyczne. Rocznik Instytutu Polonistyki Stosowanej Wydziału Polonistyki UW” 2018, r. X, t. 10, s. 55-84. 
tom mowy, m.in.: funkcjom języka, kulturze języka i normie językowej, kształtowaniu się języka w ontogenezie, mózgowym mechanizmom mowy. To dlatego w Uniwersytecie Warszawskim znalazły podatny grunt zapoczatkowane przez Jana Baudouina de Courtenay badania nad embriologia i patologia mowy i Tytusa Benniego w zakresie fonetyki eksperymentalnej, rozwijane następnie przez Witolda Doroszewskiego, Halinę Koneczna, Stanisława Skorupkę i ich współpracowników oraz uczniów. Był to dobry grunt dla narodzin i rozwoju logopedii w Uniwersytecie Warszawskim, zwłaszcza że równolegle działały w Warszawie instytucje naukowe i opiekuńcze: Instytut Głuchoniemych i Ociemniałych - założony w 1817 r. przez ks. Jakuba Falkowskiego, i Zakład Leczenia Zboczeń Mowy w Domu Zdrowia - utworzony w 1892 r. przez dr. Władysława O1tuszewskiego, a w roku 1922 powołano z inicjatywy Marii Grzegorzewskiej Państwowy Instytut Pedagogiki Specjalnej, którego zadaniem było przygotowanie specjalistów do opieki nad osobami z różnego rodzaju niepełnosprawnościami, w tym niepełnosprawnościami w zakresie mowy.

Logopedia w Polsce ukształtowała się na podstawie działalności edukacyjno-terapeutycznej pedagogów i lekarzy oraz towarzyszącej tej działalności refleksji nad celami i skutecznymi metodami pracy $z$ osobami $z$ niepełnosprawnościami $\mathrm{w}$ zakresie słyszenia-mówienia, jąkania się $\mathrm{i}$ innych trudności w mówieniu. Językoznawstwo $z$ wielu powodów nie uczestniczyło początkowo w tym procesie. Sytuacja zaczęła się zmieniać $\mathrm{w}$ połowie XIX $\mathrm{w}$. wraz $\mathrm{z}$ rosnącym zainteresowaniem językami nowożytnymi i tzw. przełomem pozytywistycznym $\mathrm{w}$ nauce,$^{2} \mathrm{w}$ którym niebagatelna rolę odegrała tzw. szkoła młodogramatyków. ${ }^{3}$

W związku z poglądami młodogramatyków na język, zwłaszcza $z$ poglądem o psychofizjologicznym statusie języka, pozostaje zainteresowanie się językoznawców zagadnieniem trudności w mówieniu.

Spośród badaczy, którzy odegrali szczególną rolę w zainicjowaniu badań nad fizjologia mowy na przełomie wieków XIX i XX na pierwszym

${ }^{2} \mathrm{~W}$ językoznawstwie przełom ten przejawił się w tym między innymi, że język zaczęto postrzegać jako zjawisko psychofizjologiczne, którego najważniejszym elementem jest działanie, tzn. mówienie. Przyjęcie $z$ kolei poglądu o psychofizjologicznym statusie języka i uznaniu, że mówienie jest najważniejszym przejawem języka stało się podstawa teorii psychologicznej języka Wilhelma Wundta [Die Sprache, 1900], szczytowego osiagnięcia szkoły młodogramatyków, którzy odegrali doniosłą rolę w powstaniu współczesnego językoznawstwa [por. Heinz 1978, 178-184].

3 Młodogramatycy pozostawali na gruncie językoznawstwa diachronicznego, historyczno-porównawczego, interesowały ich jednak, w przeciwieństwie do poprzedników, wyłącznie języki istniejące historycznie, a zmiany w języku, głównie fonetyczne i morfologiczne, opisywali, poszukujac ich przyczyny i celu (przyjmowali założenie, że zmiany w języku maja charakter celowy). Badali konkretne fakty językowe oraz - co jest ważne $z$ punktu widzenia przedmiotu niniejszego artykułu-konkretne os oby mówiące [por. Heinz 1978, 178-184]. 
miejscu należy wymienić J a na $\mathrm{Niecisława} \mathrm{Baudouina} \mathrm{de} \mathrm{Co-}$ u r t e n a y (1845-1929) - absolwenta warszawskiej Szkoły Głównej i profesora Uniwersytetu Warszawskiego, wybitnego językoznawcę polskiego i europejskiego, autora m.in. pionierskich prac z zakresu embriologii i patologii mowy, zwłaszcza: Fonologii (fonetyki) polskiej [1998]; Charakterystyki psychologicznej jezyka polskiego [1915]; Zarysu historii jezyka polskiego [1922]; por. Kaczmarek 1983. J. Baudouin de Courtenay polemizował $z$ teza młodogramatyków o stałości i niezmienności tzw. praw głosowych. W swoich pracach, m.in. w odczycie wygłoszonym w $1892 \mathrm{r}$. O pewnym stałym kierunku zmian jezykowych w zwiazku $z$ antropologia, w artykule $O$ „prawach głosowych” [„Rocznik Slawistyczny” 1910, III] oraz w Zarysie historii strony wymawianiowo-słuchowej myślenia językowego polskiego [rozdz. II Zarysu historii języka polskiego] występował przeciwko istnieniu niezmiennych, stałych „praw głosowych”. W Zarysie historii strony wymawianiowo-słuchowej myślenia językowego polskiego tak o tym pisał m.in.:

(...) pod wpływem warunków sąsiedztwa i położenia w wyrazie, w połączeniu wyrazów i.t.p. znikły całe fonemy, mieszczące w sobie owe elementy, albo też dzięki temu, że wyszły $z$ użycia całe wyrazy lub choćby tylko całe morfemy $z$ owemi fonemami $\mathrm{i}$ ich drobniejszymi częściami. O ile jednak owe najprostsze elementy ws.-e nie znikły, t.j. o ile odtwarzały się w dalszym ciagu wraz $z$ mieszczącymi je w swym składzie fonemami, stwierdzamy następujące fakty historyczne, świadczące $z$ jednej strony o zachowawczości czyli konserwatyzmie językowym, $z$ drugiej zaś o zmienności, przeradzaniu się i nowem kombinowaniu elementów [Baudouin de Courtenay 1922; cytat na podstawie przedruku z 1984, 115; pisownia zgodna $z$ oryginałem].

Jan Baudouin de Courtenay podkreślał w swoich pracach zarówno społeczny charakter jezyka i jego funkcję komunikacyjna, jak i jego wymiar psychologiczny - uważał, że język jest funkcja psychiki człowieka [por. Basara, Szymczak1984, 6].

Ważną rolę w rozwoju językoznawczego nurtu w logopedii odegrał profesor Uniwersytetu Warszawskiego Tytus Ben ni (1877-1935) - prekursor fonetyki opisowej i eksperymentalnej w Polsce, autor takich m.in. prac, jak: O akcencie polskim. Spostrzeżenia i pomiary [1912] - publikacja oparta na eksperymentalnych badaniach kimograficznych, Opis fonetyczny jezyka polskiego [1915], Metoda palatograficzna $w$ zastosowaniu do głosek polskich [1917], Ortofonia polska. Uwagi o wzorowej wymowie dla artystów, nauczycieli i wykształconego ogółu [1924], Palatogramy polskie [1931]. Publikacje te sa ważne w historii polskich badań fonetycznych i miały duży wpływ na kształtowanie się normy wymawianiowej języka polskiego, a tym samym na rozwój logopedii [por. Kania 1971].

Tytus Benni angażował się w prace organizacyjne i dydaktyczne na rzecz osób $z$ niepełnosprawnościami. Zorganizował m.in.:

- w 1917 r. - pierwszy w Polsce kurs fonetyczny dla surdopedagogów; 
- w 1920 r. - Państwowy Instytut Fonetyczny (PIF) im. J. Siestrzyńskiego przy Instytucie Głuchoniemych i Ociemniałych w Warszawie; w PIF kształcili się nauczyciele dzieci głuchych [Głowacki 1967, 69];

- w 1921 r. Poradnię Ortofoniczna przy Instytucie Głuchoniemych i Ociemniałych w Warszawie;

- w 1929 r. Instytut Fonetyczny (IF) w Uniwersytecie Warszawskim. IF odegrał istotna rolę w pracach nad opisem normy wymawianiowej Polaków i odkrywaniem mózgowych mechanizmów mowy.

Tytus Benni współpracował z założonym w 1922 r. przez Marię Grzegorzewska Państwowym Instytutem Pedagogiki Specjalnej (PIPS) w Warszawie, w którym prowadził w latach 1922-1926 wykłady $z$ fonetyki. Był też inicjatorem przeniesienia Poradni Ortofonicznej z Instytutu Głuchoniemych do PIPS.

Tytus Benni jest autorem prac poświęconych uczeniu osób niesłyszacych mowy, m.in.: Czytanie mowy $z$ ust dla ogłuchłych $w$ wieku późniejszym w świetle psychologii i fizjologii mowy [„Szkoła Specjalna” 1926/1927]; Metoda graficzna przy nauczaniu głuchoniemych mowy [„Nauczyciel Głuchoniemych i Ociemniałych” 1928].

Ważną rolę w kształtowaniu się i rozwoju badań nad językiem w działaniu i patologii mowy odegrał Witold Doros zew s ki (1899-1976) - twórca współczesnej teorii kultury języka, badacz gwar ludowych na Mazowszu, Podlasiu, Warmii i Mazurach, leksykograf oraz inicjator badań nad neurofizjologicznymi podstawami rozwoju języka i błędów językowych [Fizjologiczny mechanizm błędów językowych, 1950]. Jego postawę badawczą cechował (1) pragmatyzm - skupiał uwagę na działaniu językowym; (2) zainteresowanie psychofizjologicznymi aspektami i determinantami mówienia - nawiazywał do psychologicznej teorii bodziec-reakcja, akceptował pawłowizm, interesował się afazja jako zaburzeniem mowy, współpracował z zespołem badajacym neurofizjologiczne aspekty języka kierowanym przez Jerzego Konorskiego; (3) zainteresowanie socjologicznymi uwarunkowaniami zmian językowych - badał mechanizmy zmian językowych i ewolucji języka pod wpływem czynników społecznych [Pelc 1978; por. też Porayski-Pomsta 2016a].

$\mathrm{Z}$ inicjatywy Witolda Doroszewskiego zaczęto prowadzić w Uniwersytecie Warszawskim badania nad zaburzeniami mowy.

Ta rola Witolda Doroszewskiego, zważywszy że kierował językoznawstwem polonistycznym w Uniwersytecie Warszawskim przez lat niemal 40 (1930-1969) i wychował takich m.in. badaczy jak: Stanisław Skorupka, Halina Mierzejewska i Bożena Wierzchowska - zasłużonych dla rozwoju logopedii, jest nie do przecenienia.

Bliską współpracownica T. Benniego i W. Doroszewskiego była $\mathrm{Ha}$ lina Świderska-Koneczna (1899-1961) - kierujaca po śmierci Tytusa Benniego Instytutem Fonetycznym UW, badaczka, która dzięki oryginalności poglądów opartych na rzetelnych badaniach mocno zazna- 
czyła swoje miejsce w polskim i slawistycznym językoznawstwie - w fonetyce eksperymentalnej, dialektologii, historii języka, morfologii i składni oraz leksykografii, autorka wielu prac, m.in. wydanej pośmiertnie Charakterystyki fonetycznej języka polskiego [1965], której wartość tak podkreślał Witold Doroszewski we Wstępie do tej publikacji:

Prof. Halina Koneczna była człowiekiem o niezwykle zharmonizowanych cechach osobowości i charakteru. Dociekliwość myślowa kazała Jej nie poprzestawać w pracy naukowej na przyjętych sądach i uogólnieniach, ale szukać własnych rozstrzygnięć i odpowiedzi na pytania, które sama sobie zadawała, systematycznie gromadzić dane doświadczalne, skrupulatnie, wnikliwie analizować te dane, pracować nad nimi dopóty, dopóki nie zaczna przeświecać poprzez obserwowane fakty ogólne tendencje rozwojowe dające się formułować w jasnych, ugruntowanych sądach. Ta postawa metodologiczna Autorki znalazła szczególnie dobitny wyraz w Charakterystyce fonetycznej języka polskiego, która była ostatnim dziełem Jej życia [Doroszewski 1965, 7].

Charakterystyczne dla badań naukowych Haliny Konecznej - nie tylko synchronicznych, ale także diachronicznych - było to, że ich źródłem były obserwacje i analizy żywej mowy współczesnych jej Polaków, które stanowiły podstawę formułowania wniosków o charakterze teoretycznym i aplikacyjnym. Charakter aplikacyjny miała po części realizowana przez Halinę Koneczna dydaktyka, zwłaszcza zajęcia, które prowadziła w Państwowym Instytucie Pedagogiki Specjalnej - na prośbę prof. Marii Grzegorzewskiej - od 1951 roku niemal do swojej śmierci. Wykorzystywała tam wiedzę zdobytą w wyniku badań rentgenograficznych, pokazując słuchaczom, jak można pracować nad artykulacją osób głuchych. Żywo interesowała się w ogóle zaburzeniami mowy, gdyż uważała, że badania nad patologia mowy moga wyjaśnić wiele zjawisk z zakresu jej fizjologii [Janeczko 1998]. Interesowała się też żywo rozwojem mowy dzieci w wieku przedszkolnym, czego świadectwem jest artykuł opublikowany na łamach „Wychowania w Przedszkolu” w 1951 r. [por. Porayski-Pomsta 2019].

Szczególne, bezpośrednie zasługi dla logopedii w Uniwersytecie Warszawskim należy przypisać I r e n i e S ty c z ek (1924-1985) - uczennicy i współpracownicy Haliny Konecznej, językoznawcy, logopedzie, nauczycielowi akademickiemu, organizatorce Podyplomowego Studium Ortofonii Szkolnej i Podyplomowego Studium Logopedycznego UW oraz głównej autorce programów kształcenia w obu studiach (o czym jeszcze w drugiej części tego artykułu) [por. Porayski-Pomsta 2018].

Zainteresowania naukowe przyszłej autorki Logopedii ujawniły się już na początku studiów uniwersyteckich na warszawskiej polonistyce, na co wskazuje przede wszystkim to, że już na drugim roku zwiazała się $z$ Instytutem Fonetycznym, którym kierowała Halina Koneczna, i podjęła współpracę $z$ Poradnią Fonetyczną Kliniki Otolaryngologii Akademii Medycznej w Warszawie. Efektem tej współpracy była praca magisterska na temat Mowa u źle słyszacych, napisana pod kierunkiem Haliny Ko- 
necznej [1952], oraz rozprawa doktorska pt. Badania eksperymentalne spirantów polskich s, š, ś ze stanowiska fizjologii i patologii mowy ${ }^{4}$ [1965], przygotowana pod opieka naukowa Stanisława Skorupki i opublikowana przez Ossolineum w 1973 r. [Styczek 1973].

Rozprawa doktorska jest kontynuacja - co podkreśla autorka - eksperymentalnych badań fonetycznych prowadzonych przez Tytusa Benniego i Haline Koneczna. Irena Styczek poszerza te badania: przeprowadza je na większej liczbie osób - 44 (Benni - 1, Koneczna - kilka), prowadzi je też jednocześnie za pomoca trzech metod: rentgenograficznej, palatograficznej i lingwograficznej, a nie jednej, jak T. Benni (metoda palatograficzna) czy H. Koneczna (metoda rentgenograficzna), zwiększa liczbę prób badawczych: rentgenogramy - wykonane w Klinice Radiologicznej Akademii Medycznej w Warszawie - w czasie spoczynku i w czasie mówienia, palatogramy, lingwogramy oraz nagrania fonetyczne - wykonane w Zakładzie Fonetyki UW - zawieraja trzy wykonane w różnym czasie wymówienia, co ma tę zaletę - stwierdza ich autorka - że „(...) występowanie tych samych cech wymawianiowych na wszystkich dokumentacjach jest sprawdzianem ich dokładności i wyklucza przypadkowość", uwzględnia też nie tylko prawidłową wymowę spirantów, ale również wadliwą, co autorka uzasadnia tym, że „(...) pewne fakty $z$ zakresu patologii mowy moga ułatwić poznanie tych właściwości wymawianiowych spirantów, które nie są określane w sposób jednolity" [Styczek 1973, 5-7].

W samej metodzie badawczej, którą Irena Styczek zastosowała w badaniach, wyraźnie uwidacznia się nie tylko ich poznawczy, czysto naukowy charakter, ale właśnie społeczny, użytkowy. Zgodnie $z$ przyjętymi założeniami konfrontacja prawidłowych wymówień spirantów polskich $z$ ich realizacjami wadliwymi powinna pomóc ustalić w sposób pewniejszy niż dotychczas normę wymawianiowa w tym zakresie, a także opisać, na czym owe nieprawidłowe realizacje polegaja i jaka jest ich przyczyna, co $z$ kolei powinno bezpośrednio służyć pracy usprawniającej mowę osób tego potrzebujących.

Irena Styczek była jednak przede wszystkim logopedą. Jej poglądy na to, czym jest logopedia, wyraźnie różnią się od poglądów Leona Kaczmarka, który pierwszy próbował opisać przedmiot logopedii. W jej ujęciu logopedia to nauka interdyscyplinarna - dziedzina $z$ pogranicza różnych dyscyplin naukowych, przede wszystkim językoznawstwa, psychologii mowy, neurologii i foniatrii [Styczek 1979,6$].{ }^{5} \mathrm{~W}$ obrębie tak zdefinio-

4 Maria Przybysz-Piwko podkreśla we wspomnieniu o Irenie Styczek, że „Rozpatrywanie zjawisk fonetycznych na szerokim tle ogólnojęzykoznawczym i fizjologicznym, właściwe metodzie prof. Haliny Konecznej i szkole prof. Witolda Doroszewskiego, umożliwiało Irenie Styczek poznawanie mechanizmów zaburzeń mowy" [Przybysz-Piwko 1984, 146].

5 Wcześniej I. Styczek umieszcza logopedię w obrębie nauk pedagogicznych i zalicza do defektologii; fonetykę, foniatrię, psychologię i inne nauki traktuje jako wspierające logopedię [Styczek 1962, 362]. 
wanej dziedziny wiedzy wyróżnia: 1) logopedię ogólną albo szkolna - zajmujaca się kształtowaniem prawidłowej mowy w przedszkolu i szkole oraz doskonaleniem wymowy już ukształtowanej; 2) logopedię specjalna - zajmująca się odchyleniami od normy w zakresie mówienia i rozumienia „mowy językowej”: usuwaniem wad mowy, nauczaniem mowy w wypadku jej braku, usuwaniem trudności w czytaniu i pisaniu [Styczek 1979, 13-14].

To podejście Ireny Styczek do logopedii jako dziedziny naukowej znajdzie odbicie w jej publikacjach, zwłaszcza w Logopedii [1970] i w opracowanych przez nia programach studiów logopedycznych.

Sylwetki uczonych przedstawione w tej części artykułu pokazuja, jakie znaczenie dla narodzin i rozwoju logopedii w Uniwersytecie Warszawskim mieli ci wybitni językoznawcy.

\section{KSZTALCENIE LOGOPEDÓW W UNIWERSYTECIE WARSZAWSKIM}

\section{Studia podyplomowe}

Początki kształcenia logopedów w Uniwersytecie Warszawskim są zwiazane $z$ powołanym w 1974 r. - dzięki staraniom Ireny Styczek oraz Mieczysława Szymczaka i Stanisława Skorupki - Podyplomowym Studium Ortofonii Szkolnej (PSOS).

Powołanie na mocy Zarządzenia Ministra Nauki, Szkolnictwa Wyższego i Techniki z dnia 27 października 1973 r. Podyplomowego Studium Ortofonii Szkolnej było następstwem dwóch powiazanych ze sobą zjawisk: 1) obserwowanej od wczesnych lat pięćdziesiątych i zgłaszanej władzom oświatowym wzrastajacej liczby dzieci z zaburzeniami mowy, ${ }^{6}$ 2) ożywionej w Warszawie działalności na rzecz dzieci z zaburzeniami mowy. ${ }^{7}$

6 Obserwacje te w dużym stopniu wiążą się $z$ rzeczywistym postępem alfabetyzacji w Polsce, wykraczajacej znacznie poza ośrodki miejskie i wydłużeniem obowiazkowej nauki szkolnej do siedmiu lat (należy przypomnieć, że w okresie międzywojennym obowiazkowe nauczanie ograniczone było do lat czterech), w związku z czym postulowane były programy opieki logopedycznej (por. opracowany przez Leona Kaczmarka Model opieki logopedycznej w Polsce [1991]). Jednocześnie ożywiły się badania nad psychopedagogicznymi, neurologicznymi i językoznawczymi aspektami rozwoju i zaburzeń mowy dzieci, por. zwłaszcza: Kaczmarek 1953; Smoczyński 1955; Spionek 1970; Szuman 1958, 1968; Zarębina 1965; Mystkowska 1970.

7 Tu należy wymienić działalność utworzonych w Warszawie w latach 50. XX w. placówek: Ortofonicznej Centralnej Poradni Międzyszkolnej (później: Stołecznej Przychodni Higieny Szkolnej) i Poradni Logopedycznej Wojewódzkiej Przychodni Higieny Szkolnej (dokładniejsze informacje o działalności tych placówek w kontekście rozwoju logopedii warszawskiej w: Porayski-Pomsta, Emiluta-Rozya 2018, 64-65). 
PSOS było częścia składową Zakładu Fonetyki ${ }^{8}$, którym kierował wówczas prof. Stanisław Skorupka. Kierownikiem Studium została dr Irena Styczek.

W programie dwusemestralnego Studium, przeznaczonego dla absolwentów studiów pedagogicznych, znalazły się następujące przedmioty: fonetyka $z$ elementami gramatyki opisowej, kultura żywego słowa, elementy pedagogiki specjalnej, anatomia i fizjologia aparatu mowy $z$ uwzględnieniem typów zaburzeń mowy, wybrane zagadnienia $z$ psychologii dziecka, neurologia i psychiatria dziecięca, wybrane zagadnienia $z$ psychologii klinicznej $z$ uwzględnieniem dysleksji, dysgrafii oraz zaburzeń mowy o podłożu organicznym, rozwój mowy dziecka, wady wymowy u dzieci szkolnych i zasady reedukacji, elementy logopedii, zaburzenia głosu u dzieci i zapobieganie ich powstawaniu, zajęcia praktyczne. W sumie program obejmował 180 godzin wykładów, konwersatoriów i ćwiczeń; te ostatnie (64 godziny) były prowadzone w postaci hospitacji lekcji. Program opracowała Irena Styczek we współpracy ze Stanisławem Skorupka i Elżbieta Stecko. Można go uznać za minimum programowe studiów logopedycznych.

Słuchaczami PSOS byli absolwenci studiów pedagogicznych. Większość miała za soba praktykę w ośrodkach rehabilitacyjnych. Zajęcia były prowadzone przeważnie w formie konwersatoriów i ćwiczeń.

Żywot Podyplomowego Studium Ortofonii Szkolnej był krótki, gdyż ograniczył się do jednego roku (PSOS ukończył jeden rocznik studentów). Od początku jego utworzenia władze Instytutu Filologii Polskiej UW starały się o wydłużenie studiów do trzech semestrów. Starania te zakończyły się powodzeniem i w 1975 roku zostało powołane Podyplomowe Studium Logopedyczne (PSLog).

Program studiów PSLog został zbudowany na podstawie programu PSOS. Jego główną autorką była Irena Styczek, która kierowała Studium do roku 1977, kiedy na skutek choroby złożyła rezygnację. Nowym kierownikiem została Janina Wójtowicz - doświadczony glottodydaktyk, autorka podręczników do nauczania języka polskiego jako obcego - która wprowadziła dość istotne zmiany programowe, wzbogacając wyraźnie lingwistyczne podstawy logopedii. W 1980 roku PSLog, działające w ramach organizacyjnych Instytutu Języka Polskiego, ${ }^{9}$ wzbogaciło się o Poradnię Logopedyczną i Telefoniczną Poradnię Logopedyczną. Obie placówki, które świadczyły usługi diagnostyczno-terapeutyczne na rzecz dzieci

8 Zakład Fonetyki to dawny Instytut Fonetyki, o którym wcześniej była mowa.

9 W 1976 roku nastapiła kolejna reorganizacja na Uniwersytecie Warszawskim. Został utworzony Wydział Polonistyki, w którego strukturze organizacyjnej znalazły się dwa instytuty polonistyczne, wyłonione $z$ dotychczasowego Instytutu Filologii Polskiej: Instytut Literatury Polskiej i Instytut Języka Polskiego. Dyrektorem IJP został prof. Mieczysław Szymczak. 
z trudnościami w mówieniu, pisaniu i czytaniu, stanowiły naturalne zaplecze badawcze oraz stwarzały możliwość odbywania przez słuchaczy PSLog zajęć praktycznych. Poradnią Logopedyczna kierowała Danuta Antos - polonistka i logopeda, wspólautorka (z Irena Styczek i Genowefa Demel) poradnika Jak usuwać seplenienie i inne wady wymowy [1967]. Telefoniczna Poradnia Logopedyczna działała dzięki dyżurom bezinteresownie prowadzonym przez pracowników PSLog, m.in. Hannę Lewandowska, Marię Przybysz-Piwko, Hannę Rodak oraz słuchaczy II roku PSLog.

Jednocześnie poszerzało się pole zainteresowań badawczo-diagnostyczno-terapeutycznych pracowników PSLog, co skutkowało wzbogacaniem programu zajęć dydaktycznych w Studium. Dobrym tego przykładem jest zorganizowanie w Uniwersytecie Warszawskim w 1982 r., przy współudziale Przychodni Medycyny Szkolnej w Warszawie, kursu terapii w zakresie jakania. Celem kursu miało być przygotowanie kadry Studium do prowadzenia przedmiotu teoria i terapia jakania.

Wraz $z$ poszerzaniem oferty dydaktycznej PSLog wzrastało zainteresowanie studiami logopedycznymi i prestiż instytucji. Doceniły to władze Uniwersytetu Warszawskiego, które wystapiły w 1983 r. do Ministerstwa Nauki, Szkolnictwa Wyższego i Techniki z dwoma wnioskami: 1) o zmianę nazwy z: Podyplomowe Studium Logopedyczne na: Pomagisterskie Studium Logopedyczne, 2) o prawo wydawania absolwentom PSLog dyplomów ukończenia studium $z$ tytułem zawodowym logopedy dyplomowanego. Ministerstwo zaakceptowało obydwa wnioski władz uczelni.

W 1990 roku - po śmierci Janiny Wójtowicz - kierowanie PSLog powierzono dr Marii Przybysz-Piwko, która w 1986 r. obroniła rozprawę doktorską pt. Afatyczne zakłócenia leksemów polskich przygotowana pod opieka naukowa prof. dr hab. Haliny Mierzejewskiej. M. Przybysz-Piwko była po I. Styczek, pod której kierunkiem przygotowywała się do zawodu logopedy terapeuty, drugim zawodowym logopeda kierujacym PSLog. Doskonale znała potrzeby, możliwości i ograniczenia studiów podyplomowych. W ciagu 18 lat zarzadzania PSLog (1990-2003; 2008-2010) wielokrotnie kierowała pracami nad zmianami programowymi studiów, włączając do programu zwłaszcza zagadnienia $z$ pogranicza lingwistyki i logopedii: rozpad systemu językowego w afazji, rozwój językowy dzieci $z$ trudnościami w czytaniu i pisaniu, zagadnienia dysleksji rozwojowej, świadomość fonologiczna i fonemowa dzieci z ryzykiem dysleksji, zagadnienia niedokształcenia mowy pochodzenia korowego, usprawnianie logopedyczne dzieci $z$ dysleksja rozwojowa. Modyfikacje programowe zaproponowane i wprowadzone do programu studiów przez Marię Przybysz-Piwko bardzo poszerzyły ofertę edukacyjna. Okres, kiedy kierowała PSLog, należy uznać za najbardziej owocny. Studium cieszyło się ogromnym prestiżem w Polsce. O przyjęcie do niego starały się osoby $z$ całego kraju, mimo że przyjęcia odbywały się na podstawie trudnego egzaminu wstępnego [por. Wolańska 2018]. 
Lata od 1990 r. do dzisiaj to okres dynamicznych zmian w Polsce, zwłaszcza politycznych, które odbiły się również w związku z kolejnymi ustawami o nauce i szkolnictwie wyższym na organizacji studiów i warunkach studiowania. Zmiany te należy ocenić, $z$ jednej strony, jako pozytywne, pozwalały one i pozwalają dalej na tworzenie nowych kierunków i programów studiów, które, co naturalne, odbiegają od dwudziestowiecznego modelu studiowania, stwarzają większe możliwości podejmowania studiów o charakterze interdyscyplinarnym i unikatowym. $Z$ drugiej strony rozporzadzenia władz odpowiedzialnych za politykę edukacyjna próbuja ograniczać możliwości tworzenia tego rodzaju studiów, narzucając uczelniom konieczność dostosowania się do ustalonej przez te władze w sposób arbitralny siatki dziedzin i dyscyplin naukowych, co bardzo utrudnia wpisanie m.in. (a może zwłaszcza) logopedii do określonej dziedziny naukowej.

Program studiów PSLog był wielokrotnie modyfikowany. Obecnie program ten, rozpisany na cztery semestry, jest niezwykle rozbudowany. Składa się nań 45 przedmiotów: 21 spośród nich to przedmioty poświęcone zaburzeniom mowy (mówienia, rozumienia, pisania i czytania) o zróżnicowanej etiologii oraz przedmioty z zakresu metodyki postępowania logopedycznego (dwa: autokorekcja i emisja głosu służą samodoskonaleniu się przyszłych logopedów); 6 przedmiotów przeznaczono na zagadnienia językoznawcze (fonetyka akustyczna i audiologiczna, fonetyka artykulacyjna, fonologia języka polskiego, dialektologia, ortofonia i grafetyka); 3 przedmioty medyczne (anatomia i fizjologia układu nerwowego, narządów mowy, głosu i słuchu, foniatria, psychiatria dziecięca); 4 przedmioty z zakresu psychologii i psycholingwistyki (neuropsychologia, psychologia rozwojowa i kliniczna dziecka, rozwój językowy dziecka, wspomaganie rozwoju psychoruchowego i komunikacja interpersonalna). Program ten uzupełniaja: seminarium dyplomowe oraz praktyki logopedyczne. Studia kończą się praca dyplomową oraz egzaminem dyplomowym.

Modyfikacje te, które doprowadziły do aktualnego stanu, miały podstawy: naukowe - logopedia stopniowo stawała się, jakkolwiek nieformalnie, odrębna dyscyplina naukowa, co powodowało konieczność zmian i modyfikacji programowych, tak by słuchacze mogli zdobywać aktualna wiedzę; praktyczna - w zakresie diagnozy, opieki i terapii logopedycznej, co było wynikiem pogłębionej współpracy $z$ lekarzami, psychologami i pedagogami; prawno-administracyjna - organizacja studium i programy nauczania w nim obowiąujące musiały zostać dostosowane do wymogów ministerialnych i uczelnianych. Tym obowiazkom musieli podołać kolejni kierownicy PSLog: Krzysztof Szamburski (2003-2008) i Ewa Wolańska (2010-2020). ${ }^{10}$ Trzeba jeszcze dodać, że od 2014 r. PSLog funk-

10 Od 2021 r. PSLog kieruje Joanna Zawadka, która zapewne czekają ważne decyzje programowe. 
cjonuje w obrębie struktury Centrum Logopedycznego Instytutu Polonistyki Stosowanej Uniwersytetu Warszawskiego.

\section{Studia licencjackie i magisterskie w zakresie logopedii}

Wzrasta wiedza o zaburzeniach mowy. W klasyfikacjach chorób pojawiaja się schorzenia do niedawna zupełnie nieznane, których skutki odbijają się na sprawnościach w mówieniu, czytaniu, pisaniu i rozumieniu, zwłaszcza dzieci i młodzieży. Zawód logopedy wymaga coraz bardziej różnorodnej i jednocześnie coraz bardziej specjalistycznej wiedzy oraz dużych umiejętności. Jednocześnie wzrasta zapotrzebowanie na przygotowanie specjalistów do prowadzenia logopedycznych badań klinicznych ważnych $z$ diagnostycznego punktu widzenia.

W przedstawionej sytuacji kształcenie logopedów na studiach podyplomowych przestało być wystarczające, co w środowisku logopedycznym uświadamiano sobie od pewnego czasu. Doświadczenia związane z kształceniem od roku 1989 logopedów w Wyższej Szkole Pedagogiki Specjalnej (później: Akademii Pedagogiki Specjalnej) na studiach dziennych pokazały także, że kształcenie logopedów w trybie studiów stacjonarnych jest bardziej efektywne.

W roku akademickim 1998/1999 w Instytucie Języka Polskiego UW opracowano na kierunku filologia polska w ramach specjalizacji nauczycielskiej program podspecjalizacji logopedycznej. Mogli się na nia zapisywać studenci IV roku studiów, którzy po uzyskaniu dyplomu magistra mieli prawo do kontynuacji studiów logopedycznych na II roku PSLog i po zaliczeniu zajęć programowych uzyskiwali dyplom logopedy. Już w kolejnym roku akademickim dziekan Wydziału Polonistyki, prof. dr hab. Stanisław Dubisz, wyraził zgodę na uruchomienie specjalności logopedycznej. Dla zapewnienia realizacji programu studiów został też utworzony w Instytucie Języka Polskiego Zakład Fonetyki i Logopedii.

Program studiów na tej specjalności był niezwykle rozbudowany. Studenci, którzy byli przyjmowani na specjalność w wyniku odrębnego postępowania rekrutacyjnego na I rok studiów, realizowali dwa pełne programy studiów: filologii polskiej i logopedii, jednocześnie byli zobowiązani do podjęcia studiów nauczycielskich. Studia trwały 5 lat. Kolejne roczniki studentów miały nieco ograniczony program studiów w zakresie literaturoznawstwa oraz przedmiotów historycznojęzykowych.

Ponieważ studia te były bardzo kosztowne, zaczęto poszukiwać sposobu na obniżenie kosztów własnych Wydziału. Wówczas pojawiła się idea powołania konsorcjum odpowiedzialnego za prowadzenie studiów logopedycznych, które mogłyby stworzyć trzy uczelnie: Uniwersytet Warszawski - Akademia Pedagogiki Specjalnej - Warszawski Uniwersytet Medyczny. Przychylność władz Wydziału Polonistyki i władz rektorskich UW pozwoliła rozpocząć w 2007 r. rozmowy dotyczące tego przedsięwzięcia. Ostatecznie do próby utworzenia konsorcjum przystapily dwie 
uczelnie: Uniwersytet Warszawski i Warszawski Uniwersytet Medyczny. Na przełomie lat 2008 i 2009 została opracowana pierwsza wersja programu studiów. W grudniu 2009 r. zostało podpisane przez rektorów UW i WUM porozumienie o wspólnym prowadzeniu studiów logopedycznych. W 2010 r. obie uczelnie - każda osobno - uzyskały zgodę Ministra Nauki i Szkolnictwa Wyższego na otwarcie kierunku studiów licencjackich (trzyletnich) i magisterskich (dwuletnich) pod nazwą log o pedia ogólna i kliniczna (LOiK). ${ }^{11}$

Na Wydziale Polonistyki UW pierwszy nabór na kierunek został przeprowadzony na rok akademicki 2010/2011.

Studia na LOiK sa prowadzone przez utworzony w 2007 roku Instytut Polonistyki Stosowanej (IPS) UW [por. Dubisz 2013]. ${ }^{12}$

Program studiów na kierunku logopedia ogólna i kliniczna, który ewoluował w ciagu dziesięciu lat, zbudowany został w postaci bloków tematycznych, na studiach licencjackich: 1. Lingwistyczne aspekty logopedii (390 g.), 2. Medyczne aspekty logopedii (355 g.), 3. Psychopedagogiczne aspekty logopedii (150 g.), 4. Praktyka logopedyczna (385 g.), 5. Metodyka pracy $z$ małym dzieckiem (300 g.); na studiach magisterskich: 1. Lingwistyczne podstawy logopedii (30 g.), 2. Medyczne podstawy logopedii (135 g.), 3. Logopedia (405 g.). ${ }^{13}$

Od roku akademickiego 2016/2017 na studiach licencjackich były prowadzone dwie specjalności: ogólna (LOiK) oraz logopedia szkolna i dydaktyka polonistyczna. ${ }^{14} \mathrm{~W}$ związku ze zmianami, które zostały wprowadzone przez ustawę Prawo o szkolnictwie wyższym i nauce z dnia 20 lipca 2018 r., specjalność nauczycielską zamknięto.

Studia na kierunku logopedia ogólna i kliniczna umożliwiły uzyskanie dyplomów licencjackich i magisterskich kilkuset absolwentom LOiK, pozwoliły też na wypromowanie około dwudziestu doktorów i czterech doktorów habilitowanych. Bardzo też wzbogaciła się logopedyczna kadra dydaktyczna i naukowa. Tworzy ja pięciu doktorów habilitowanych, ośmiu doktorów i jeden magister.

11 Bardziej szczegółowo zostało to opisane w: Porayski-Pomsta 2013, 20-30; Porayski-Pomsta, Emiluta-Rozya 2018, 77-81.

12 Należy wyjaśnić, że w wyniku decyzji administracyjnych władz obu uczelni program LOiK, analogiczny na UW i WUM, jest realizowany osobno, chociaż zajęcia dydaktyczne odbywają się wspólnie w UW i WUM. Wydział Polonistyki i I Wydział Lekarski „świadczą sobie nawzajem usługi dydaktyczne”.

13 Podana tu informacja odnosi się do pierwszej wersji programu realizowanego w latach 2010-2013 - na studiach licencjackich i 2013-2015 - na studiach magisterskich.

14 Idea specjalności szkolnej wiąała się z potrzebą odpowiedniego przygotowania nauczycieli języka polskiego do sprawowania opieki logopedycznej w szkołach powszechnych i integracyjnych. W programie logopedii szkolnej, obok przedmiotów logopedycznych, uwzględniono minima programowe $z$ zakresu literaturoznawstwa i językoznawstwa oraz dydaktyki nauczania języka polskiego. 


\section{ZAKOŃCZENIE}

W artykule przedstawiłem historię kształtowania się myśli o rozwoju i zaburzeniach mowy oraz historię studiów logopedycznych w Uniwersytecie Warszawskim. Zamiarem moim było zaprezentowanie, $z$ jednej strony, wybranych sylwetek językoznawców, którzy najsilniej, jak sądzę, wpłynęli na rozwój tego nurtu badań językoznawczych, na rozwój badań nad zaburzeniami i dysfunkcjami mowy i języka, $z$ drugiej strony - dziejów kształcenia logopedycznego w UW.

Badania językoznawcze stanowiły rodzaj podglebia, na którym wyrosła logopedia w Uniwersytecie Warszawskim. Zaczyn stanowiła myś1 Jana Baudouina de Courtenay. Zarówno Witold Doroszewski - w opisie mechanizmów błędów językowych, jak i Tytus Benni - w badaniach w zakresie fonetyki eksperymentalnej oraz Halina Koneczna - w prezentacji relacji pomiędzy dialektami a językiem ogólnopolskim i w fonetyce eksperymentalnej nawiazują do spuścizny Baudouinowskiej.

Naukowe prace logopedyczne i okołologopedyczne: Bożeny Wierzchowskiej, Haliny Mierzejewskiej, Ireny Styczek, Marii Chmury-Klekotowej, Marii Przybysz-Piwko i badaczy logopedów z młodszego pokolenia ukształtowały się na tym właśnie podłożu.

Na tym samym podłożu powstały programy studiów logopedycznych w Uniwersytecie Warszawskim i ramy organizacyjne kształcenia logopedów zapoczątkowane w 1974 r. I w jednym, i w drugim wypadku ważna rola przypada Instytutowi Fonetycznemu Uniwersytetu Warszawskiego.

Logopedię jako dziedzinę badań i kierunek kształcenia czekaja dalsze zmiany. Wynika to zarówno $z$ ewolucji samej logopedii jako dziedziny naukowej, jak i ze wzrastajacych potrzeb w zakresie kształcenia kadr logopedycznych. Byłoby dobrze, aby kierunek tych zmian nawiazywał $\mathrm{w}$ takim stopniu, jak to możliwe, do dorobku naszych poprzedników.

\section{Bibliografia}

J. Baudouin de Courtenay, 1922, Zarys historii języka polskiego, Warszawa. Przedruk [w:] J. Basara, M. Szymczak (red.), 1984, Jan Baudouin de Courtenay o jezyku polskim, Warszawa, s. 19-138.

W. Doroszewski, 1965, Profesor Halina Koneczna (1899-1961) [w:] H. Koneczna, Charakterystyka fonetyczna języka polskiego na tle języków słowiańskich, Warszawa, s. 5-7.

S. Dubisz, 2013, Instytut Polonistyki Stosowanej 2007-2012 - geneza i perspektywy, „Studia Pragmalingwistyczne” V, s. 9-18.

J. Głowacki, 1967, Szkolnictwo dla głuchych w Polsce w okresie międzywojennym [w:] O. Lipkowski (red.), O wychowaniu dzieci gtuchych, Warszawa, s. 57-72.

S. Grabias, 2012, Teoria zaburzeń mowy. Perspektywy badań, typologie zaburzeń, procedury postępowania [w:] S. Grabias, M. Kurkowski (red. nauk.), Logopedia. Teoria zaburzeń mowy, Lublin, s. 15-71. 
A. Heinz, 1978, Dzieje językoznawstwa w zarysie, Warszawa.

M. Janeczko, 1998, Halina Koneczna (1899-1961), „Szkoła Specjalna”, numer specjalny, s. 241-242.

L. Kaczmarek, 1953, Kształtowanie się mowy dziecka, Poznań.

L. Kaczmarek, 1983, Jan Baudouin de Courtenay - prekursor nowoczesnej logopedii, „Logopedia. Zagadnienia Kultury Żywego Słowa” t. 14-15, s. 5-14.

L. Kaczmarek, 1991, Model opieki logopedycznej w Polsce, Gdańsk, s. 5-41.

J.T. Kania, 1971, Sylwetki naukowe pionierów logopedii $i$ dyscyplin pokrewnych: Tytus Benni, „Logopedia. Zagadnienia Kultury Żywego Słowa” t. 10, s. $143-148$.

H. Mierzejewska, 1977, Afatyczna dezintegracja fonetycznej postaci wyrazów, Wrocław.

H. Mierzejewska, M. Chmura-Klekot, 1975, Jan Baudouin de Courtenay, „Logopedia. Kultura żywego słowa” t. 12, s. 96-110.

M.A. Paveau, G.E. Sarfati, 2009, Wielkie teorie językoznawcze. Od językoznawstwa historyczno-porównawczego do pragmatyki, tłum. I. Piechnik, Kraków.

J. Pelc, 1978, Wspomnienie pozgonne o Witoldzie Doroszewskim i Julianie Krzyżanowskim, „Studia Semiotyczne” VIII, Wrocław, s. 5-10, nadb.

J. Porayski-Pomsta, 2013, Kierunek studiów logopedia ogólna $i$ kliniczna $w$ Instytucie Polonistyki Stosowanej Uniwersytetu Warszawskiego, „Studia Pragmalingwistyczne" V, s. 19-30.

J. Porayski-Pomsta, 2016a, Witold Doroszewski-pozytywista i organizator życia naukowego, „Poradnik Językowy” z. 1, s. 67-76.

J. Porayski-Pomsta, 2016b, Witold Jan Doroszewski (1899-1976), „Poradnik Językowy" z. 3, s. 81-85.

J. Porayski-Pomsta, 2018, Irena Styczek-językoznawca i logopeda [w:] Z. Greń, K. Kleszczowa, Z. Zaron (red.), My z Nich 2. Spuścizna językoznawców polskich drugiej połowy XX wieku, Warszawa, s. 147-155.

J. Porayski-Pomsta, 2019, Halina Świderska-Koneczna-uczona, nauczyciel akademicki i organizator życia naukowego [w:] Z. Greń, K. Kleszczowa, Z. Zaron, My z Nich 3. Spuścizna językoznawców polskich drugiej połowy XX wieku, Warszawa, s. 123-134.

J. Porayski-Pomsta, 2020, Halina Mierzejewska - jezykoznawca, afazjolog, wspóttwórca polskiej logopedii 2. połowy XX wieku [w:] Z. Greń, K. Kleszczowa, Z. Zaron, My z Nich 4. Spuścizna językoznawców polskich XX wieku, Warszawa, s. 117-128.

J. Porayski-Pomsta, D. Emiluta-Rozya, 2018, Logopedia warszawska. Historia i czasy współczesne, „Studia Pragmalingwistyczne” X, s. 55-86.

M. Przybysz-Piwko, 1984, Doktor Irena Styczek (14 IX 1924-28 IV 1981), „Poradnik Językowy” z. 3, s. 146-150.

I. Styczek, 1970, Zarys logopedii, Warszawa.

I. Styczek, 1973, Badania eksperymentalne spirantów polskich s, š, ś ze stanowiska fizjologii o patologii mowy, Wrocław.

I. Styczek, 1979, Logopedia, Warszawa.

E. Wolańska, Maria Przybysz-Piwko jako wspóttwórczyni nowoczesnej logopedii na Uniwersytecie Warszawskim, „Studia Pragmalingwistyczne” X, s. 35-52. 


\section{Logopaedics at the University of Warsaw}

\section{Summary}

The paper entitled Logopaedics at the University of Warsaw is composed of two sections. Section one discusses profiles of the following linguists: Jan Baudouin de Courtenay, Tytus Benni, Witold Doroszewski, Halina Koneczna, and Irena Styczek, whose academic research and organisational activity contributed most to the formation of the research on speech acquisition, development, and disorders at the University of Warsaw. Section two presents the history of establishing institutions training speech therapists at the University of Warsaw: Podyplomowe Studium Ortofonii Szkolnej (Postgraduate Studies of School Orthophony), Podyplomowe (later: Pomagisterskie) Studium Logopedyczne (Postgraduate Studies of Logopaedics), and various organisational forms and frameworks of training speech therapists as part of full-time programmes.

Keywords: Polish linguistics - experimental phonetics - logopaedics - cerebral mechanisms of speech and language - embryology of speech - speech pathology - speech therapy - speech therapist training.

Trans. Monika Czarnecka 